\title{
Infrastructure Development in Papua: Features and Challenges
}

\author{
Fadhli Zul Fauzi ${ }^{1}$ \\ A. A. Gede Brahmantya Murti ${ }^{2}$ \\ Laili Alfiati Imamah ${ }^{3}$ \\ Nimas Hapsari ${ }^{4}$
}

\begin{abstract}
This article aims to examine the issue of infrastructure development in Papua Province, Indonesia. This article specifically discusses the problems confronted during the process of infrastructure development in Jayapura and the challenges in expanding them. The method used in this study is the qualitative method with a case study approach, wherein the infrastructure development case selected is the Papua Bangkit Stadium and Holtekamp Bridge located in Jayapura. Both infrastructure development cases serve as sample cases that show the extent of infrastructure development impact in Papua, and the issues that were confronted, starting from the development process up to the expansion. The study results indicate that although previous studies have shown positive correlation between development and welfare, in reality, there are several problems occurring in Papua's infrastructure development. Preparedness of human resources, cultural issues, and weak coordination between every level of regional government institution, these are the main problems in Papua's infrastructure development. This article is expected to assist in resolving the issues found in Papua's infrastructure development, and to provide recommendations for resolving those issues.
\end{abstract}

\section{Keywords:}

infrastructure problems; Papua; local government; cultural context

\section{Introduction}

Development in underdeveloped regions is aimed at removing inequality with other regions, in various aspects relating to education, knowledge, health, and economy (FernándezSerrano, Martínez-Román, \& Romero, 2018; Mahmud \& Akita, 2019). Infrastructure is a part of development that is considered to have the ability to enhance regional capacity, so that a region can subsequently maintain competitiveness against other regions (Demurger, 2001). Waromi (2018) states that infrastructure refers to physical systems that provides transportation, irrigation, drainage, buildings, and other public facilities

\footnotetext{
${ }^{1}$ Department of Public Policy and Management, Faculty of Social and Political Sciences, Universitas Gadjah Mada. (Corresponding Author)

Email: fadhli.zul.f@mail.ugm.ac.id

${ }^{2}$ Department of Public Policy and Management, Faculty of Social and Political Sciences, Universitas Gadjah Mada. Email: gde.brahmantya@mail.ugm.ac.id

${ }^{3}$ Department of Public Policy and Management, Faculty of Social and Political Sciences, Universitas Gadjah Mada. Email: laili.alfiati.i@mail.ugm.ac.id

${ }^{4}$ Department of Public Policy and Management, Faculty of Social and Political Sciences, Universitas Gadjah Mada. Email: nimashapsari2018@mail.ugm.ac.id
} 
necessary to fulfill basic human needs. This means that the infrastructure system serves as the main support of social functions and the economic system in the community's daily life. Public participation in the national development process is, thus, a key requisite that underlies the success of infrastructure development in a country (Waromi, 2018).

As of current, Papua Province and West Papua Province are among the main focus of the Indonesian Government in terms of infrastructure development programs for underdeveloped and remote regions (Anggraini, 2018). One of the government's main domestic policies is to develop and improve infrastructure throughout the archipelago, by conducting programs such as developments of toll roads, rail roads, bridges, and even stadiums that are considered to boost local economy and the community's life standard. Infrastructure development such as the Trans-Papua road project which spans $1,070.62 \mathrm{~km}$ on the West section of Trans-Papua road, and 68 bridges completed in 2016, with as many as 195 bridges that continued to be developed until 2018 (Anggraini, 2018). Hence, development in Papua is not merely carried out by the regional government as it is also conducted by the central government through the development of the Papua Bangkit Stadium and the Holtekamp Bridge that were made by a State-Owned Enterprise (Badan Usaha Milik Negara - BUMN), namely PT Pembangunan Perumahan (Persero) Tbk (PTPP).

However, INDEF data instead indicates that infrastructure development in the current Indonesian Government administration does not have a significant impact on employment creation. A number of impacts from projects conducted in Papua in the last few decades do not indicate meaningful continuity, successful implementation of projects in other regions in Indonesia and abroad should, accordingly, be reconsidered before being executed in Papua (Karim, 2012).
The reason for this is believed to be the low level of public participation in the infrastructure development planning and implementation process. This is indicated by the implementation of development programs throughout all community levels, wherein the human development index of Papua Province remains at the lowest rank in Indonesia (Karim, 2012). Public participation in development should not only be considered as a part of the process, but it should also be seen as a part of the objective, in which participation is one of the indicators of successful development (Waromi, 2018). Waromi (2018) also argues that the form of public participation may also refer to the form of public contribution given to the development itself. Public participation contribution surely differs in every region, depending on the stage of program implementation (Karim, 2012).

Basically, infrastructure development in Papua is still being carried out today to enhance Papua's capacity so that it can effectively compete with other regions in Indonesia. Various aspects of health infrastructure, education infrastructure, and other supporting infrastructure are being finalized and improved, or even developed in order to maintain local wisdom elements so that they would be more easily adopted by the community (Gokkon, 2017). However, there are still problems occurring in Papua's infrastructure development as of current, starting from issues relating to preparedness of human resources to other cultural issues. This study intends to examine the role of infrastructure development in regional development, particularly in Jayapura Municipality, Papua. The infrastructure development projects analyzed in this study were the Papua Bangkit Stadium and the Holtekamp Bridge located in Jayapura Municipality.

There are few studies on the impact of infrastructure development in Papua. This research, accordingly, intends to dig 
deeper into the significance of infrastructure development in Papua, which is indeed put under the spotlight of the government, because undoubtedly a lot more benefits can be gained when focusing greater attention to the master plan, so more engineering and feasibility studies are required before continuing with huge investments as they can minimize costs and provide far more progressive impacts in the future.

\section{Methods}

This study employs the case study approach as a part of the qualitative research. Case study is a research strategy in which researchers thoroughly examines a program, an event, an activity, a process, or a group of individuals (Creswell, 2010). The aim of using the case study approach is to describe how something happened and why it happened (Yin, 2011). The case study approach allows us to examine a particular social condition, situation, or event and to provide insight about the process describing how a particular event or situation occurred (Hodgetts \& Stolte, 2012). According to Hodgetts \& Stolte (2012), case study on individuals, groups, communities helps to show crucial matters of attention, a community's social process in a concrete event, experiences of stakeholders.

This study was conducted to understand more deeply how the entire process unfolded, the obstacles faced, and the strategy carried out in Jayapura's infrastructure development, as well as the impacts they had on the community. The locations of study in this research are the Papua Bangkit Stadium and the Holtekam Bridge. Papua Bangkit Stadium was chosen as one of the cases in this study because the stadium will ultimately be used for the National Sports Week (Pekan Olahraga Nasional - PON) in 2020, while Holtekamp Bridge was selected because it is considered to facilitate public access for Papuans in the years to come. By examining the two cases, we can see the extent of the problems and the advantages brought about by these infrastructure developments, as well as recent developments of issues regarding the two projects.

There were six sources utilized to collect data for this study, namely: documents, archival records, interviews, direct observations, participant observations, and physical equipment (Yin, 2011). In this study, the data collection stage was carried out by interviewing key informants who know in detail the development process of Holtekam Bridge and Papua Bangkit Stadium, along with documents relating to the development. The entire data collection process was obtained through direct observation at the study locations.

In terms of data collection process (Sugiyono, 2017), observation can be distinguished into participant observation and non-participant observation. According to Sugiyono (2008), in participant observation, the researcher is engaged in the daily activities of the person being observed or the person utilized as a source of research data. Meanwhile, in non-participant observation (Creswell, 2010), the researcher remains uninvolved and merely acts as an independent observer. Non-participant observation (Sugiyono, 2017), is an observation process that is carried out without participating in the life of the person being observed and it stipulates a separate position as an observer. In this study, data collection was done by using the non-participant observation method, wherein the researcher conducts direct observation at the location of study as an independent observer without being directly involved in the infrastructure development implementation process. Consequently, in this case, the researcher was capable of gaining more detailed information from the confessions given by the source persons who were directly involved in the development process. 


\section{Results and Discussion \\ The Role of Infrastructure in Development}

Infrastructure development is considered as one of the means to improve the quality and quantity of economic growth and community welfare (Adu-Boahen, et al., 2014). Previous studies indicate that adequate infrastructure availability has direct impact on the growth of regional or national productivity as a whole (Sahoo \& Dash, 2012; Manggat, Zain, \& Jamaluddin, 2018; Khan \& Bakar, 2017). Availability of physical infrastructure, both basic and supporting infrastructure, is regarded to hold a significant role in increasing economic growth (Sahoo \& Dash, 2009). Basic infrastructure developments such as transportation, electricity, water, sanitation, and health facilities have a highly crucial role in increasing community welfare in underdeveloped areas (Ghosh, 2017). Infrastructure provision in the transportation sector, such as roads and bridges, is also considered to have substantial influence on the development of a region's economic growth by offering ease of access to every community living in the region (Demurger, 2001; Munim \& Schramm, 2018; Lenz, Skender, \& Mirkovic, 2018).

Meanwhile, it is considered that weak infrastructure development may have influence on the disparity of community welfare between one region and another (Manggat, Zain, \& Jamaluddin, 2018). One of study results presented by Demurger (2001) shows that there is correlation between infrastructure growth and disparity among provinces in China. Differences in the implementation of infrastructure policies and public investment target of each region are believed to have influenced economic growth in every province in China (Demurger, 2001). Based on previous studies, infrastructure does indeed have a vital influence on the economic growth of a country or region in the micro context. Differences in the government's role are also considered to have direct influence on the differences in infrastructure growth between one region and another (Chatterjee \& Turnovsky, 2012; Sahoo \& Dash, 2009).

The influence of government's role on infrastructure growth may be observed from differences in financial policies or infrastructure policies determined by the respective governments, and from the consideration of time duration that the government has to conduct infrastructure development (Demurger, 2001; Chatterjee \& Turnovsky, 2012). One of the examples can be seen from the case of the Government of India's role to develop their policy in order to conduct planning in the field of infrastructure on a massive scale in collaboration with the private sector, and it ultimately brought about extremely rapid growth and investment circle (Sahoo \& Dash, 2009). Another case in China also indicates that the weakness of the regional government's role in implementing the central government's infrastructure policy had eventually led to a disparity among the regions (Demurger, 2001).

Additionally, another study in Italy shows that the role of infrastructure in development directly influences public capacity, wherein infrastructure development is considered capable of enhancing all aspects of public capacity and potential (Agenor \& MorenoDodson, 2006). However, this should also be supported by the regional government's role to carry out planning in preparing the community to develop and expand existing infrastructure potentials (Hult \& Bradley, 2017). Regional government is also considered capable of creating policies that empower the community in the infrastructure development process, such as educating and involving the public in developing and maintaining infrastructure (Seyfang, 2011). If the role of the local government could be fully maximized and the community could be adequately empowered, infrastructure development can, as consequence, enhance the community's capacity and potentials. 
Infrastructure development, as observed from the previous descriptions above, does indeed have numerous benefits in both regional and national development. Based on prior studies, infrastructure development can boost economic growth, generate greater prosperity for the community, and enhance public capacity. However, there are, undeniably, a variety of issues confronted by every region or country implementing infrastructure development, and this depends on the government's role and other aspects as elaborated in the numerous cases above. This study intends to examine the extent of the impact that infrastructure development has in Papua by looking at the various aspects found in the previous studies, and to explore the problems that occurred in Papua's infrastructure development. The cultural aspect is also one of the focus of attention in this article on account of the intensity of the cultural element in development in Papua.

\section{The Context of Papua: Problems and Challenges}

Development in Papua, such as the TransPapua toll road had indeed been initiated since the Soeharto era and it was halted in 1998 on account of the monetary crisis (Firdauzi, 2018). Upon observation of past policies, there is a difference in policy approach between the past and present. Development policy in the past government utilized the security approach rather than the welfare approach (Suriadi, Kundjono, \& Osnidar, 2010). The result of a study conducted by UNDP in collaboration with scholars and NGO states that there are currently substantial gaps of various aspects in Papua, namely gaps between regions and communities; between urban and rural/isolated communities; indigenous and rural residents in terms of access to public services, and other development facilities (Suriadi, Kundjono, \& Osnidar, 2010). Infrastructure development such as roads, bridges, buildings, would certainly have an impact on the surrounding area. Taking road construction as an example, according to Mc. Kay, Reneche, and Goshi (as cited in Adisasmita, 2005, p. 175), road construction in rural areas has an influence on lowering the cost of transportation and facilitating in the shipment of goods, additionally, there are also positive impacts brought about by road constructions, which are increasing vehicular mobility; increasing human mobility from isolated villages; increasing public enthusiasm to manage existing natural resources; and increased awareness among the community of the need for education, electricity, clean water, and so on. There are several challenges confronted in infrastructure development in Papua, namely human resource, geographical conditions, as well as cultural and sociological challenges.

\section{a. Human Resource Challenges}

Some of the challenges relating to human resource refer to the imbalance between the natural resources managed and the human resource available, since there is still a lack of human resource quality and quantity (Kulla et al., 2018). Morever, Kulla (2018) elaborates that the human resource issue is also associated with the lack of competence which obstructs development improvement, wherein people do not have higher level education competence and they lack knowledge pertaining to science and technology as required by industrialization.

\section{b. Geographical Challenges}

Papua has an extremely large geographical area with wide-ranging conditions making it impossible to conduct development equally throughout the region. With a total land area of $768,000 \mathrm{~km}^{2}, 71 \%$ of Papua's land consists of tropical rain forest with exceedingly difficult to reach areas due to the numerous valleys and high mountainous terrains in the area. Such diverse regional conditions have led to an uneven population distribution that is in line 
with the geographical conditions of the area people live in (Geost, 2019). Such geographical conditions are often used to justify the reasons for some groups to discredit Papua, perhaps this could also provide an outlook of the existing obstacles in Papua. According to the Head of the Road Construction Agency Region XVIII of Papua and West Papua, Osman H. Marbun (2017), the challenges in development, particularly of the TransPapua road construction is the geographical conditions and topography of some of the areas as the workers had to break through forests, cut through mountains, and bury swamps.

\section{c. Cultural and sociological challenges}

The prevalent security threat of organizations pursuing Papua's independence (Free Papua Movement or Organisasi Papua Merdeka-OPM) makes it difficult to carry out development projects in remote rural areas. Indigenous Papuan peoples still live separately and spread out in small communities making it difficult for development implementation to reach them entirely in unison. According to the Papua study team of the Indonesian Institute of Sciences (Lembaga Ilmu Pengetahuan Indonesia - LIPI), regarding the root causes of the problems in Papua, including the actors and their interests, there are at least four that can be identified, namely: 1 . The marginalization of and discrimination against the indigenous people of Papua. For instance, not all Papuans are provided adequate services due to infrastructure conditions that remain unconnected to remote and isolated Papua regions. 2. Suboptimal development in Papua. The special autonomy fund spent by the government as of 2017 amounted to 63.8 trillion rupiahs. Despite the substantial amount of special autonomy fund available, cases of famine and malnutrition, which still occur in places like Asmat, implore the need to evaluate the effectiveness of the special autonomy fund. 3. Human rights violations and violence remain. The shooting case in Nduga Regency is proof that violence still occurs in Papua. From the case, it is known that the perpetrators of violence were not only the security forces, but the OPM military wing group as well. 4. Pros and cons about the unfinished process of Papua integration into Indonesia (Elisabeth, 2018).

The infrastructure made were often uneconomical because the number of people who enjoy the development outcome is not proportional with the amount of cost spent or the cost that has to be spent or the cost that has to be spent is not proportionate with with the benefits gained (Suriadi, Kundjono, \& Osnidar, 2010).

Obstacles are things that become an obstruction and it may come from both inside or outside of the subject in progress. In the case of infrastructure development in Papua, there were undoubtedly obstacles confronted along the way. According to our field observations and expansion of references we found, the form of obstacles that hinders infrastructure development in Papua may be categorized into obstacles that come from within (internal) and outside of (external) the Papua region. Concerning internal obstacles, there are geographical obstacle, sociocultural obstacle, and human resource obstacle. As for external obstacles, there are regulatory and administrative obstacle and economic obstacle.

\section{Internal Obstacles}

\section{Geographical obstacles}

Papua's geographical conditions indicate a vast lush land with great potential for preservation, however, on the other hand, development also needs to be done in Papua. People who care about the environment would definitely oppose infrastructure development in Papua as the use of land for development would certainly have an impact on reducing green areas in Papua. There would also be impact from pollution generated by machines during the construction of buildings, roads, or 
other infrastructure. Conflict between people who are pro environment and pro development inevitably occurs and becomes an obstacle to infrastructure development in Papua.

Additionally, as cited from the national online newspaper Kontan, the Minister of Transportation, Budi Karya Sumadi, explained in a Limited Meeting about the Evaluation of National Priority Program and Priority Project in Papua and West Papua at the Office of the President that the geographical condition, which can be regarded as quite difficult, is one of the obstacles of infrastructure development in Papua. As a sample case, regarding the rail road project, it was said that in addition to the harsh construction terrain, there is also the issue of passenger capacity, in which the concern is that the capacity would not be proportionate to the amount of coach available. Another case is the construction of Seget Port, which is still held up by a land issue, the land area that was planned to be used for an international container port, as of the Limited Meeting conducted on July 19, remains to be indeterminate.

\section{Sociocultural obstacles}

The people of Papua still maintain strong culture and custom in their region. As a result, throughout nearly all regions of Papua, matters pertaining to land are still often associated with their customary practice causing debates among the tribal chiefs in Papua or when the central government and relevant stakeholders intend to carry out infrastructure development in Papua. The Director General of Rail Transportation of the Ministry of Transportation, Prasetyo Boeditjahjono, stated that in the period of 2018 -2019 the government plans to build the TransPapua rail road line and he mentioned that one of the obstacles in the construction project is the issue of customary land (Afriyadi, 2016).

Customary lands are land areas that maintain customary rights or authority that the customary law communities (masyarakat hukum adat) have over certain areas, and given such authority, the community, which comprises of individuals who have perpetual and hereditary physical and mental relationship with the indigenous community, are allowed to make use of and benefit from the natural resources therein, including the land for their livelihood. Land claim among tribal chiefs who consider they have the right of ownership over a certain piece of land continues to trigger conflicts and it is the biggest obstacle for infrastructure development in Papua.

Another social obstacle concerns the matter of corruption perpetrated by Papua regional government officials, which has become somewhat established within the bureaucracy. This culture of corruption emerged when the central government began focusing development in Papua and along with it came substantial amount of funding allocated through the special autonomy fund, Regional Budget, and National Budget, which were eventually misappropriated by most of the regional government officials in Papua. The regional government officials of Papua were unprepared in receiving large sums of funding allocation from the central government, and they experienced culture shock when they found that their region became the focus of Indonesian development. Hendrik Yance Udam, the Chairman of the National Executive Board for the People Love the Republic of Indonesia Movement in the National Security Council (Dewan Ketahanan Nasional - Wantanas), Jakarta as quoted in the webpage of Theinformationnews, stated that corruption is indeed flourishing in Papua along with the proliferation of separatist movements seeking to secede from the Unitary State of the Republic of Indonesia. Hendrik argues that the Free Papua issue is repeatedly publicized merely to protect corruptors from the long arm of the law, he thus expects the Indonesian Corruption Eradication Commission (KPK) to immediately address this issue so that 
development in Papua can run on the right track and bring about positive impacts not only to Papua but to Indonesia as well.

\section{Human Resource Obstacles}

Human resource is a crucial element in successful development implementation. On the other hand, infrastructure development would mean nothing if the government ignores the quality of human resource, particularly in the aspects of education and health. As cited from Media Indonesia's webpage, LIPI researcher Adriana Elisabeth in a discussion under the topic of Ember in the Land of Papua, which was held by Media Indonesia on December 15, 2018, affirmed that while conducting her research directly in Papua, she found that there is great potential for the Papuan community to advance in the field of education, there are many potential young people with great vision for the sake of Papua's advancement, yet these potentials are ignored as they are occupied by horizontal conflicts occurring among the tribes in Papua. The commitment and attention of the government is indeed very much required to accommodate those potentials for the sake of progress in Papua.

\section{External Obstacles}

\section{Regulatory and administrative obstacles}

Vague regulatory framework is one of the issues hindering development in Indonesia (PwC, 2016). This is corroborated by Lukas Enembe as the Head of Papua Province Government, who stated that although numerous changes have occurred in Papua, there were quite a lot of obstacles that had to be confronted on account of central government policies and situation that were incompatible with the regional conditions in Papua. As cited from the Papua Government official webpage, Enembe states that there are regulatory obstacles that lead development in Papua to be conducted far from the expected outcome due to the minimum authority the regional government is given. The Government of Papua will, thus, need to reflect what it would do once the special autonomy fund is depleted, because in 2021 the special autonomy authority will end. Enembe affirms that money alone is not enough to address the problems in Papua on account of its multidimensional and multifaceted regional characteristics.

Administrative issues were also observed in the Papua regional government, wherein according to data from the Ombudsman Representative for Papua Province, the organization received 136 Public Complaints/ Reports in 2018, of which mostly were from Jayapura Municipality and Jayapura Regency, then subsequently followed by other regencies in Papua. The top 5 substance of the reports/ complaints were concerning personnel affairs (27.2\%), land issues (14\%), police issues (9.5\%), education $(9.5 \%)$, and labor/employment $(8.8 \%)$. Considering the forms of dominant maladministration reported by the public, there were constant delay (36\%), inappropriate conduct $(17.6 \%)$, procedural deviation $(14.7 \%)$, no service provision (12.5\%), and abuse of authority $(6.6 \%)$. Concerning government institutions that were most reported, they were the Municipal/Regional Government (22.7\%), Ministry of Law and Human Rights (16.1\%), Papua Provincial Government (11.7\%), Departmental (Resort - Regency/Municipality level) Police (5.8\%), State-Owned Enterprise/ Region-Owned Enterprise (5.8\%), and Papua Regional (Provincial level) Police (4.4\%). Thus, it can be concluded that even in terms of public service in the administrative sector, Papua regional governments still need to improve their public administration in order to support the development programs focused in their region.

\section{Economic obstacles}

Economic obstacles refer to the way that human resource in Papua manages their resources. The exceedingly low 
entrepreneurship climate in Papua is actually quite unfortunate, bearing in mind that Papua is a region with an immense wealth of natural resources. The agricultural sector, fisheries, and tourism sector that could function as substantial income for Papua are not well managed due to the Papuans lack of understanding on their use. As cited from the webpage of IndustriBisnis.com, the President Director of PT Bank Pembangunan Daerah Papua branch, Johan Kafiar, also states that the lack of adequate infrastructure and facilities in Papua is one of the factors hindering the progress of economic climate in Papua to move forward. Accordingly, there is great expectation concerning the incessant infrastructure development conducted throughout Papua, so that business actors encounter little difficulty when intending to ship and market their products, and that consequently distribution cost remains stable and the people of Papua can enjoy the benefit of managing their own resources.

\section{Case Study: Papua Bangkit Stadium}

Infrastructure continues to be a main priority for Jokowi's administration, as indicated in 2015, when the government had determined an aggressive target, announced new funding commitment and demonstrated openness to utilize financial funding from the private sector. The funds were allocated within a period of infrastructure in 2 sectors including oil and gas, electricity, water supply and sewage treatment, irrigation, housing, roads and urban transport, railroad transportation, seaports, and airports. Nevertheless, the government admitted that this is not a continuous long-term approach for infrastructure funding.

Papua is a forest area of which a large part of it remains underdeveloped and it has long been managed as a national resources extraction frontier. As a consequence, Papua has become the focus of numerous megaprojects in the field of forestry, agriculture, and mining, with project proposals encompassing tens of millions of hectares of land in the last few decades (Carr, 1998; EIA, 2006; Rulistia, 2008). Most of these projects were executed driven by commercial interests, and a large portion of them failed to be realized as they were confronted with protests concerning environmental issues, customary issues, or global financial crisis at the end of 2000s. The case of Papua is critically distinct since it is driven by the national development agenda that is established on the concern over resource, energy, and food security.

Although the Papua case is significant, there is still a lack of study on its regional implications, even though many have been criticized locally (AwaMIFEE, 2013). Papua's status as a resources frontier results in distinctive challenges relating to conservation and development along the region's development corridor. In other Indonesian regions, development corridors promote logging, mining, and agricultural cultivation activities in sites that generally pass through previously exploited landscapes, but with some exceptions (Alamgir et al., 2018; Sloan et al., 2018a, b). As a result, local management issues would usually emerge, such as the integrity of the remaining forest, the mobility of endangered animals, and even customary issues around the corridor of the infrastructure development area.

Infrastructure development in Papua, which has indeed become the focus of the government in accordance with Nawacita (Jokowi's 9 priority programs), engages in collaboration with state-owned and private companies. PT Pembangunan Perumahan (Persero) Tbk (PTPP) is a State-Owned Enterprise (BUMN) in the field of construction that was established by the Indonesian government. The establishment of PTPP is to carry out the mandate as the government's agent in the development of housing and other construction projects. According to PTPP's business development data, it currently has 7 
(seven) lines of business that are specified into 3 (three) categories, Upstream - Midstream Downstream. The business line included in the upstream category consists of investments in the property, infrastructure, and energy sectors. While midstream comprises of the construction business, and downstream includes the business of precast concrete and low cost residential housing as well as heavy construction equipment based contractor. Activities in the construction sector play a vital role in Indonesia's infrastructure development. It is through these activities in the construction sector that acceleration and equal distribution of infrastructure development can be achieved in Indonesia. Furthermore, the construction sector is one of the driving factors in boosting Indonesia's economy. As mentioned in Bank Indonesia's 2017 Annual Report, the government intends to allocate 410 trillion rupiahs of the National Budget to the infrastructure sector in 2018. This serves as one of the indicators that Indonesia is seriously committed to enhancing infrastructure development.

The government's focus to develop infrastructure in Papua undoubtedly opens up new economic access to the people of Papua as well. Increased quality and quantity of economic growth and community welfare is acknowledged by Adu-Boahen (2014) to be the resulting impact of infrastructure development. A single pile foundation initiated the construction of the Papua Bangkit Stadium, which is a football stadium located in Harapan Village, Nolokla Sub-District, East Sentani District, Jayapura Regency, Papua Province. The stadium has a capacity of more than $40,000-45,000$ spectators. The stadium is made to hold the National Sports Week (Pekan Olahraga Nasional - PON) event in 2020, and it is designed using international standards, from its field, grass, lighting, even the athletic track, and accessibility for persons with disability is also considered in its standard of design. In terms of technology, LED lighting and timing systems in the Papua Bangkit Stadium were made with Olympic level standards. Aside from its use of the latest technology, the grand arena for the $20^{\text {th }}$ PON also maintains topnotch grass quality by using a type of grass called Zoysia Matrella, which is the standard used by FIFA in most international stadium the world over. The facilities for aquatic and athletic competitions will also be made using IAAF (International Association of Athletics Federation) standards. With utmost respect to elements of Papuan culture, the arena, which rises among Papua's natural terrain, is adorned with distinct Papuan carvings at the stadium entrance to complete the magnificence of the Papua Bangkit Stadium.

Another infrastructure development in the same compound as Papua Bangkit Stadium is currently on-going, which is a sporting complex that has been constructed since 2018 and is due to finish by mid 2020 to facilitate the $20^{\text {th }}$ PON event in Papua. According to the Construction Report presented by PTPP, the sporting complex is a two-story building with stands and rooftop. It comprises of 8 badminton courts, 1 basketball court, 6 volleyball courts, a gymnastic arena, and a warming-up arena, and it can seat 3,674 spectators and VVIPs. The sporting complex boasts a multifunction concept, as it is not only focused for sporting events but for non-sporting events as well, such as concerts, meetings or assemblies, and even religious events allowing the people of Papua to publicly utilize it. Given the international level standards applied, the construction of Papua Bangkit Stadium and the sporting complex is expected to raise Indonesia's competitive edge. Like China, constant and high economic growth was in large part brought about by massive investment in physical infrastructure that had begun since the early 1990s (Llanto, 2015). Lianto (2013) also shows the positive impacts infrastructure has on the Philippines' agricultural productivity, wherein regions with 
greater amount of investments in infrastructure had experienced higher economic growth.

Jones (2004) found interesting evidence that investment in water, sanitation, and roads is extremely crucial for growth and they have been beneficial to poor people across East Asia and the Pacific. The lack of vital infrastructure such as water, transportation, housing, and energy obstructs efforts of inclusive growth and development in poverty alleviation (Geest \& Nunez-Ferrer, 2011). A scheme illustrating how infrastructure development leads to poverty reduction is provided below.

The construction of Papua Bangkit Stadium and the sporting complex in Papua as a manifestation of infrastructure development carried out by the government and PTPP undoubtedly generates new economic potentials for Papuans, it can accordingly function as a link between the market and economic activities that may have an impact on reducing poverty rate. Nonetheless, the development of new economic potential also has its fair share of problems and obstacles. As cited from PricewaterhouseCoopers' (PwC) 2016 Annual Report on Infrastructure Development in Indonesia, there are historical obstacles that must be addressed and should be considered by any investor considering the Indonesian market:

a. The project pipe is not fully transparent.

b. Regulatory/legal frameworks for projects are sometimes uncertain.

c. The justice system is not entirely reliable to uphold contracts without taking sides and being objective.

d. The procurement process is improving but it is not always clear and transparent.

e. The government's strategies and policies are often unclear or may change within a short period of time.

f. Different public institutions may not be coordinated and may have opposing policies and objectives.

g. Many officials are reluctant to take risks and have no incentive to conduct investments.

h. Public institutions often do not have the budget for preparing high-quality project by international consultants.

i. There is a high regulatory load for new and existing businesses with numerous requirements for license to operate or carry out projects.

\section{Figure 1.}

Infrastructure Framework for inclusive growth and poverty reduction

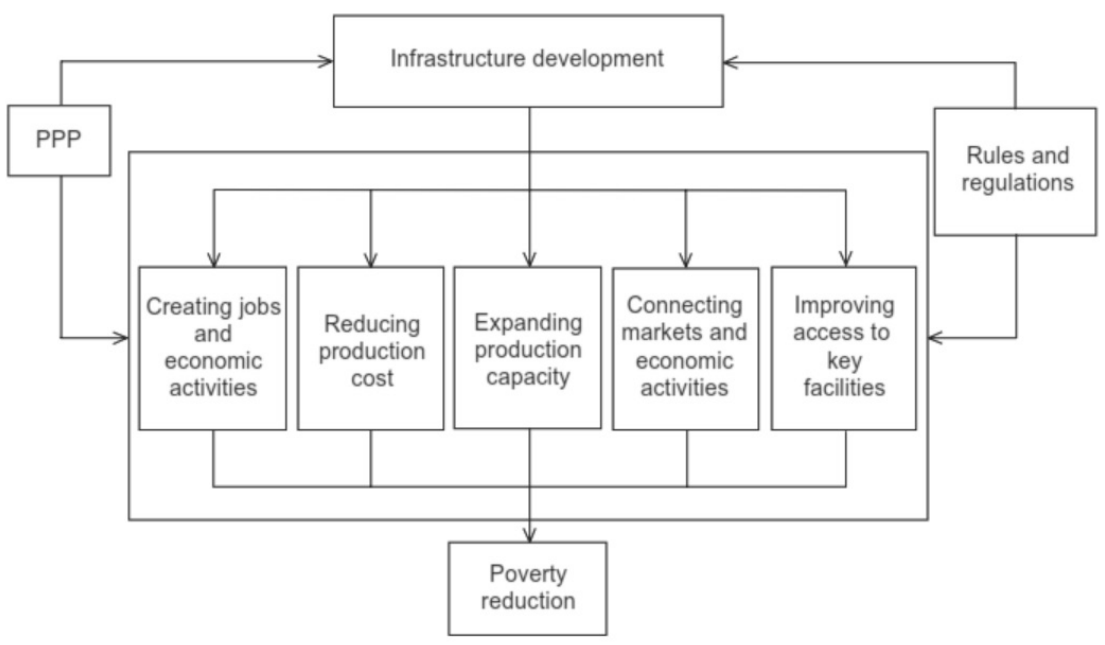

Source: Asia-Pacific Development Journal, 2015 
According to findings from the on-field observations, the obstacles mentioned above are indeed true in reality. Such as the low level of skills that Papuans possess while they are actually at the epicenter of development itself. As quoted from the Jakarta Post, Neles Tebay, the Coordinator of Papua Peace Network (Jaringan Damai Papua - JDP) and a Catholic priest, said that the government's attempt to build Papua will be futile as in some regions the local people were merely witnesses or spectators to economic activities taking place in another village because they had no access to sustainable development or were not involved due to their lack of skills and their feeling of being isolated from the activities in their own hometown. A solution relating to this issue that the researcher found while being on the field is for the regional government to provide training and assistance to the locals and for PTPP to engage with local communities in development programs and maintain the image of the company as a form of quality control. Another issue we found on the field was matters relating to land area in Papua (Customary Land).

For companies intending to carry out development projects/programs in Papua, like PTPP, the issue of land area is a key obstacle in the development process. There are several cases related with this issue, such as conflict among tribal chiefs who stake mutual claim of a particular land area, problematic resolution of customary land compensation provided by the provincial government, $0 \%$ land acquisition although the construction had been completed hence requiring the contractor, in this case PTPP, to constantly leave the old structures undamaged as long as the construction remains on-going. The lack of synergy between the Provincial and Municipal Governments has become one of the roots of the problem in matters of land area in Papua. The role of the regional government in unifying and empowering the community remains weak, hence compelling PTPP as the company in charge of several infrastructure development projects in Papua to play the role of facilitator between the community and Papua's regional governments in resolving conflicts relating to land area in Papua by using a persuasive approach carried out by PTPP's public relations team to ensure the smooth running of the development projects/programs.

The success of infrastructure development projects carried out in Papua by the government with PTPP as the stakeholder in charge of executing the projects, were by no means without obstacles. It is hoped that the development projects in Papua can become a holistic and sustainable development that does not only target infrastructure development but takes human quality development of Papuans into consideration as well so that there is harmony between infrastructure and human development in its implementation. This can be achieved by enhancing the capacity during project procurement and preparation, and new emphasis on findings, trainings, and motivation for talented individuals to manage the project. Good coordination is also required for the success of development in Papua, coordination that can create synergy between the central government, regional governments, and relevant stakeholders. Simplification and improvement of the land acquisition process and much larger budget allocation are also important matters to consider in infrastructure development since, based on recent history, these issues usually cause numerous delays in the project.

\section{Case Study: Holtekamp Bridge}

The construction of bridges and tunnels play a crucial role in local and urban economic and social development (Chen, Cao, \& Liu, 2010). According to Chen, Cao \& Liu (2010), without bridges, land masses would constantly be separated, human mobility would be limited, and local economic development would be negatively influenced. Accordingly, 
infrastructure development in the form of bridges would provide new access, connect, and facilitate detached difficult-to-reach regions.

In some countries, bridges function as a link that bring about numerous impacts and changes. Chen, Cao \& Liu (2010) in their study mention that there are 22 bridges in the city of Suzhou crisscrossing the Suzhou River in Shanghai, and these bridges link the northern and southern part of the river. Furthermore, there are numerous bridges built over the river Thames and Seine, making London and Paris into amazing metropolitan areas well-known throughout the world. New York became the center of finance and commerce after Manhattan, Long Island, Staten Island, New York, and New Jersey were connected by 65 bridges.

According to Chen, Cao \& Liu (2010), the construction of bridges is aimed at resolving issues of travel/mobility, particularly in river network areas, so that people are able to cross over quickly. In other words, bridge construction can serve as a solution for providing better access and quicker travelling time. Based on direct observation on the field, Holtekamp Bridge is a bridge constructed to connect land access from Hamadi District, South Jayapura to Holtekamp, Muara Tami District, Jayapura Municipality. The bridge is located over Youtefa Bay and it is 1,800 meters long and 17 meters wide. The construction of this bridge would cut down travelling time from Jayapura Municipality to Skouw border from 2.5 hours to just 50 minutes. Before the construction of the Holtekamp Bridge, a trip from Jayapura Municipality to the border forced people to circle around Youtefa Bay resulting in longer travelling time.

As a driver of economic growth, infrastructure such as roads and bridges play a significant role in regional development. Several empirical facts indicate that the general advancement of infrastructure capacity a region experiences is proportionate to its economic development (Calderón \& Servén, 2004; Démurger, 2001; Maryaningsih, Hermansyah, \& Savitri, 2014; Sukwika, 2018). This is due to the fact that economic development requires the availability of adequate infrastructure and facilities (Sukwika, 2018). Infrastructure improvements contribute in boosting investments and economic growth since investments subsequently increase labor absorption. According to (Siregar \& Sukwika, 2007), investment play a vital role in determining labor absorption. Good infrastructure also stimulates increase in personal income on account of progressively thriving economic activities brought about by higher production mobility and trade-related activities (Sukwika, 2018). Accordingly, infrastructure expansion has a close relationship with economic development and they are mutually dependent upon one another.

Another specific finding was identified in the result of a study by (Mahmud \& Sawada, 2018), describing the impact of the Jamuna Multipurpose Bridge (JMB), which was subsequently named Bangabandhu Bridge. It was built in 1998 as the largest infrastructure project in Bangladesh to address the integration of the labor market. In their study, Mahmud \& Swada (2018) evaluated the impacts JMB had on employment opportunities that focus on the effect of labor market integration by using survey data providing information about the current evaluation and retrospectively from the conditions of households in two neighboring regencies connected by the bridge. The research results found that the construction of the bridge had an impact on reducing the rate of household unemployment because it had facilitated agricultural workers to become nonagricultural workers. JMB connected the eastern and western part of the country, through the capital Dhaka, allowing it to facilitate economic integration and the expansion of the entire economy (Hossain, Sen, \& Sawada, 2012; 
Mahmud \& Sawada, 2018). Additionally, the construction of the bridge had a huge impact on reducing poverty by increasing farmer's income by cultivating high value crops (Bayes, 2007; Mahmud \& Sawada, 2018).

The construction of Holtekamp Bridge is predicted to drive the economy and expand the Koya area. Based on observations of the research site, there was an abundance of land spread with minimum residential area along the Koya area heading toward Skouw, people rarely inhabit this area due to separate access toward the area and longer traveling time thereby leaving the area mostly vacant without any activity. Other assets were visible on the right hand side, which was lined with mangrove forest up to a radius of $\pm 7 \mathrm{~km}$ from the entrance of the bridge. Lush trees lining the forests were seen upon entry to the Central Koya area and all along the journey heading toward Skow area. These land areas have potential economic values if they were to be managed and developed properly. With the construction of the Holtekamp Bridge along the Koya area up to the Skouw area, lands that initially saw little to no inhabitants have the potential to grow and become a new area of economic activities for Jayapura Municipality.

Additionally, Holtekamp Bridge has become a new tourism icon for the people of Papua. Based on observations on the study location, the public's enthusiasm to visit the bridge, take selfies, and enjoy the beautiful view of Youtefa Bay from the bridge was apparent. Based on conversations with PTPP's Holtekamp Bridge Construction Project Manager, Ery Supratomo, he stated that the public's enthusiasm to visit Holtekamp Bridge had been apparent since the completion of the bridge's construction and public transportation began to go across the bridge. The bridge had not been officially opened at the time so people were able to visit freely as traffic was still sparse. This indicates that besides enhancing economic potential in the tourism sector, the
Holtekamp Bridge has turned into a local icon (identity) and pride for the surrounding community.

On the other hand, the equal distribution of infrastructure development in isolated regions has shown the level of public trust in the government. Public trust refers to the trust that residents have in the state and the government, including its institutions, policies, and officials (Wahyuningsih, 2011, p. 37). Trust, according to Cheema (2010), is a multifaceted concept which concerns basic consensus among community members on collective values, priorities, and differences as well as the community's implicit acceptance of where they live. In terms of trust that refers to trust in the government, the government must engage in cooperation with relevant stakeholders in managing the expectations of their residents, because once the government is unable to manage and meet their expectations, the trust they have given will be subsequently tarnished (Cheema, 2010).

So far, the root of public distrust in the government is caused by several factors of which among them are: the public feels they are being politicized and state apparatus often abuse their power for personal interests, the public feels no connection with the government, public service is considered inadequate, the governance system does not function as it should, declining national or global economy caused by globalization, technological advancement, political scandal or crisis, or incompetent state apparatus (Kim, 2010). Additionally, the government's inability to meet public expectations leads to a public perception of the government that tends to be on the negative side. One of the consequences is declining public trust in the government (Cheema, 2010). When public expectation does not align with reality, public distrust can very easily come into being.

There have been several attempts made by the government to improve public trust in the 
last few years, among them was by issuing and creating government policies and programs that were in the public's interest. Equal distribution of infrastructure development in Papua has gradually improved the reality that had been causing Papuans' to distrust the government, and the notion that Papua has been ignored by the government in terms of development has waned.

The equal distribution of infrastructure development in Papua is by no means impervious to topographical, sociological, and cultural challenges and obstacles. Challenges emerging out of physical conditions, in terms of both topographical and geological circumstances, is that a lot of regions are located on peat lands or steep incline with thin layers of land and potential risks of landslide and erosion. Furthermore, most of the regions in Papua and West Papua have high seasonal rainfall level. The result of an interview with PTPP's Holtekamp Bridge Construction Project Manager indicates that the challenge in constructing the Holtekamp Bridge was the on site condition of the bridge, which is highly vulnerable to earthquakes, hence requiring the contractor to use high quality materials and to build a construction design that is able to withstand the existing condition. Consequently, the main construction of the bridge was designed to use steel arches spanning 112.5 meters long, standing 20 meters tall, and weighing 2,000 tons.

In addition, Papua being located at the easternmost part of Indonesia had led to greater expenses and relatively longer period for completing the infrastructure development project. The Project Manager mentioned that materials for constructing the bridge were not assembled in the island due to the fact that human resources, technology, and venue in Papua were inadequate. As a consequence, the 2,000-ton steel that had been assembled had to be shipped from Surabaya to Papua by ship traveling a distance of $3,2000 \mathrm{~km}$. This shows that issues concerning human resource and institutional capacity in Papua remain to be a huge challenge and have significant influence on infrastructure development.

From a sociological and cultural aspect, Papuans are people who uphold and revere customary practices. The subsequent challenge emerged when the infrastructure development project was built on customary land, which is extremely prone for causing conflicts. Development projects that go through customary areas owned by indigenous Papuan communities would usually be faced with an obstacle in the form of land conflict over the on-going development project area. The conflict usually begins with a claim from an indigenous customary community demanding compensation for their ownership of the land area that will be developed. If the demand of the indigenous community were not met, then they would not allow the customary area or land they own to be used for development (Wijaya, Permadi, \& Safi'i, 2018).

The construction of the Holtekamp Bridge was not merely building a bridge over Youtefa Bay, it also required the construction of new road access from the city of Jayapura toward the bridge and new road access to connect regions around the bridge toward Central Koya area to head to Skouw area. It was the construction of these new road access around the bridge that had to go through customary land owned by the indigenous community. PTPP's Public Relation Section of the Holtekamp Bridge Construction Project, Rahmat said in an interview that resolving land acquisition issue on customary land areas is no easy feat and it requires quite a substantial amount of fund.

Throughout the process of constructing new road access around the bridge, customary lands were acquisitioned by using persuasive measures to approach the indigenous community. According to PTPP's Public Relations officer, if the conflict concerning customary land area were to be resolved 
merely based on the amount of money compensated, then it would not end even after seven generations have passed. $\mathrm{He}$ stated that customary lands are owned by the community without any legal boundaries and clear administrative ownership, their legality is strictly customary and solely based on hereditary claims bestowed by ancestors to their descendants. Consequently, conflicts frequently occur among tribal chiefs who mutually stake a claim over the same plot of customary land area. According to the PR officer, such conflict would require a rather substantial amount of money for compensating the claims that may be submitted by numerous parties who consider themselves to be the rightful inheritor of the land if the issue were to be resolved by merely providing compensation without any persuasive approaches employed in advance.

The persuasive measures PTPP had taken by approaching individuals of the indigenous community and by socializing with the community, respecting their culture and prevailing customary practices, listening to the indigenous community's aspirations for their customary lands, and attempting to mediate the community and the government in customary land acquisition cases. Another step the company took was through the implementation of Corporate Social Responsibility (CSR) programs as a manifestation of the company's social responsibility to the indigenous communities that were impacted by the development project. Rahmaat stated that the company constantly tried to help fulfill the needs of the local indigenous community as a way to show the company's concern and responsibility.

Based on the on-site interview results, it can be concluded that conflicts in the acquisition of customary land areas require solid synergy between the provincial and regional/municipal governments. The lack of communication channels between the indigenous community and the regional/municipal/provincial governments may result in initial conflict over the acquisition of customary land areas. Compensation for customary rights and clarity of customary land ownership status are the shared responsibility of the provincial and regional/municipal governments, and they should be resolved before executing the infrastructure development project so that it does not lead to new losses during the construction process. Nevertheless, vertical coordination among provincial and regional/ municipal governments remain to be a problem in resolving land acquisition cases in Papua.

\section{Conclusion}

Infrastructure development in prior studies always indicates positive correlation with economic growth and the community's welfare. Meanwhile, in the case of infrastructure development in Papua, particularly in the development of the Papua Bangkit Stadium and Holtekamp Bridge, infrastructure availability is also believed to be capable of triggering economic potentials and improving community's welfare. However, there are several issues in the development of these infrastructure projects that still need to be improved so that they could provide maximum impact on economic growth and the community's welfare. The lack of solid vertical coordination between the provincial government and the regional/ municipal governments is believed to have affected the infrastructure development process and its expansion. The preparedness of human resources in Papua to manage existing infrastructure and their economic potentials is also still considered to be suboptimal. Accordingly, good coordination between all government levels (central, provincial, regional/municipal) and the community to jointly enhance infrastructure development and management is necessary.

Cultural issues such as customary land also remains to be a recurring problem in 
the infrastructure development process in Papua. The government should pay serious attention to resolve customary land issues that still continue to this day in Papua, because land acquisition issues often thwart the infrastructure development process and delay the development target planned by the contractors. Aside from coordination among the stakeholders, cultural issues should also be a crucial concern in Papua's infrastructure development. Once these problems are addressed and resolved, infrastructure development in Papua would undoubtedly run at an optimal level.

Additionally, the regional government should also play their role of empowering Papuan communities upon the completion of the infrastructure development. The government should provide capacity building programs to the people of Papua so that the potentials unlocked by the infrastructure can be developed and expanded by the local communities. Programs to enhance the skills of the community are beneficial in helping the people of Papua participate in managing existing infrastructure. Furthermore, provision of plots of land by the government may also help develop the potentials of Papuan communities. For instance, the provision of plots of land in the Papua Bangkit Stadium area for Papuans so that it could be managed by the community for selling souvenirs or Papuan delicacies. So that, ultimately, infrastructure development will also have a direct impact on economic growth and welfare of people living in Papua.

\section{Acknowledgement}

The researchers would like to express their appreciation to board chairman of PT PP (Persero) Tbk, Andi Gani Nena Wea, who has supported and funded this field research to Papua, Indonesia.

\section{References}

Adu-Boahen, K., Antwi, K. B., Mensah, E. A., Atampugre, G., Osman, A., Osei, K. N., \& Adu-Boahen, A. O. (2014). Role of rural infrastructural development in alleviating poverty in Ghana: A case of Jukwa, Central Region. International Journal of Development and Sustainability, 4(3), 737-748.

Afriyadi, A. D. (2016). Ini alasan sulitnya bangun infrastruktur di Papua. Retrieved August 7, 2019, from https://www.liputan6.com/ bisnis/read/2515384/ini-alasan-sulitnyabangun-infrastruktur-di-papua?utm_ex pid=.9Z4i5ypGQeGiS7w9arwTvQ.0\& utm_referrer=https $\% 3 \mathrm{~A} \% 2 \mathrm{~F} \% 2 \mathrm{Fwww}$. google.com $\% 2 \mathrm{~F}$

Agenor, P. R., \& Moreno-Dodson, B. (2006). Public infrastructure and growth: New channels and policy implications. Retrieved from https://papers.ssrn. com/ sol3/papers.cfm?abstract_id=2005043. doi:10.2139/ssrn.2005043.

Bayes, A. (2007). Impact assessment of Jamuna Multipurpose Bridge Project (JMBP) on poverty reduction. Japan: Report prepared for the Japan Bank for International Cooperation (JBIC).

Calderón, C., \& Servén, L. (2004). The effects of infrastructure development on growth and income distribution. Working Papers No. 3400 .

Chatterjee, S., \& Turnovsky, S. J. (2012). Infrastructure and inequality. European Economic Review, 56(8), 1730-1745.

Cheema, G. (2010). Building trust in government: An introduction. In G. Cheema, \& V. Popovski (Eds.), Building trust in government: Innovation in governance reform in Asia (pp. 1-21). New York: United Nations University Press.

Chen, J., Cao, Y., \& Liu, J. (2010). Bridges, tunnels and their relationship to the economic development on both sides of Taiwan strait. Marine Georesources and Geotechnology, 21(34), 261-267. doi: 10.1080/713773400 
Creswell, J. (2010). Research design: Pendekatan kualitatif, kuantitatif, dan mixed. Yogyakarta: Pustaka Pelajar.

Démurger, S. (2001). Infrastructure development and economic growth: An explanation for regional disparities in China?. Journal of Comparative Economics, 29(1), 95-117. doi: 10.1006/jcec.2000.1693

Fernández-Serrano, J., Martínez-Román, J. A., \& Romero, I. (2018). The entrepreneur in the regional innovation system. A comparative study for high- and low-income regions. Entrepreneurship \& Regional Development, An International Journal, 31(5-6), 1-20, doi: 10.1080/08985626.2018.1513079

Ghosh, M. (2017). Infrastructure and development in Rural India. Margin-The Journal of Applied Economic Research, 11(3), 256-289. doi: 10.1177/0973801017703499

Hodgetts, D., \& Stolte, O. (2012). Case-based research in community and social psychology: Introduction to the special issue. Journal of Community $\mathcal{E}$ Applied Social Psychology, 22(5), 379-389. doi: 10.1002/casp.2124

Hossain, M., Sen, B., \& Sawada, Y. (2012). Jobs, growth and development: Making of the "Other" Bangladesh, background paper for the World Development Report 2013 Jobs. Washington: World Bank.

Hult, A., \& Bradley, K. (2017). Planning for sharing - Providing infrastructure for citizens to be makers and sharers. Planning Theory E Practice, 18(4), 597-615. doi: 10.1080/14649357.2017.1321776

Khan, M. A., \& Bakar, A. N. (2017). The role of infrastructure in national economic development: Evidence from Malaysia. International Journal of Economic Perspectives, 11(4), 630-637.

Kim, S. (2010). Building trust by improving governance: Searching for feasible way for developing country. Public Administration Quarterly, 34(3), 271-229. doi: $10.2307 / 41288350$
Lenz, N. V., Skender, H. P., \& Mirkovic, P. A. (2018). The macroeconomic effects of transport infrastructure on economic growth: The case of Central and Eastern E.U. member states. Economic ResearchEkonomska Istrazivanja, 31(1), 1953-1964. doi: 10.1080/1331677X.2018.1523740

Mahmud, M., \& Sawada, Y. (2018). Infrastructure and well-being: Employment effects of Jamuna bridge in Bangladesh. Journal of Development Effectiveness, 10(3), 327-340. doi: 10.1080/19439342.2018.1483415

Mahmud, S. S., \& Akita, T. (2019). Urban and rural dimensions of the role of education in income inequality in Bangladesh. Review of Urban \& Regional Development Studies, 30(3), 170-183. doi: 10.1111/ rurd.12089

Manggat, I., Zain, R., \& Jamaluddin, Z. (2018). The impact of infrastructure development on rural communities: A literature review. International of Academic Research in Business E Social Sciences, 8(1), 647-658. doi: 10.6007/IJARBSS/v8-i1/3837

Maryaningsih, N., Hermansyah, O., \& Savitri, M. (2014). Pengaruh infrastruktur terhadap pertumbuhan ekonomi Indonesia. Buletin Ekonomi Moneter dan Perbankan, 61-98.

Munim, Z. H., \& Schramm, H.-J. (2018). The impacts of port infrastructure and logistics performance on economic growth: The mediating role of seaborne trade. Journal of Shipping and Trade, 3(1), 1-19. doi: 10.1186/s41072-018-0027-0

Sahoo, P., \& Dash, R. K. (2009). Infrastructure developmentand economicgrowthinIndia. Journal of the Asia Pacific Economy, 14(4), 351-365. doi: 10.1080/13547860903169340 Sahoo, P., \& Dash, R. K. (2012). Economic growth in South Asia: Role of infrastructure. The Journal of International Trade $\mathcal{E}$ Economic Development: An International and Comparative Review, 21(2), 217-252. doi: 10.1080/09638191003596994 
Seyfang, G. (2011). The new economics of sustainable consumption - Seeds of change. London: Palgrave Macmillian.

Siregar, H., \& Sukwika, T. (2007). Faktor-faktor yang mempengaruhi kinerja pasar tenaga kerja dan implikasi kebijakannya terhadap sektor pertanian di Kabupaten Bogor. SOCA (Socio-Economic of Agriculture and Agribusiness), 7(3), 1-22.

Sugiyono. (2017). Metode penelitian kualitatif, kuantitatif, dan RED. Bandung:Alfabeta, CV.

Sukwika, T. (2018). Peran pembangunan infrastruktur terhadap ketimpangan ekonomi antarwilayah di Indonesia. Jurnal Wilayah dan Lingkungan, 6(2), 115130. doi: 10.14710/jwl.6.2.115-130
Suriadi, A. J., Kundjono, \& Osnidar. (2010). Peran infrastruktur jalan terhadap dinamika sosial dan ekonomi di kawasan perbatasan Indonesia-Papua New Guinea. Jurnal Sosek Pekerjaan Umum, 2(1), 21-36.

Wijaya, A. I., Permadi, I., \& Safi'i, R. I. (2018). Penyelesaian sengketa tanah ulayat pada proyek pembangunan jalan di Papua Barat (Studi Kasus di Kabupaten Sorong Papua Barat). Jurnal Hukum JATISWARA, 33(3), 313-330. doi: 10.29303/jatiswara.v33i3.180 Yin, R. K. (2011). Studi Kasus Desain dan Metode. Jakarta: Raja Grafindo Persada. 